\title{
AgEING AND Fiscal IMBALANCES ACROSS GENERATIONS: CONCEPTS OF MEASUREMENT
}

\author{
ROBERT FENGE \\ MARTIN WERDING
}

CESIFO WORKING PAPER NO. 842

CATEGORY 3: SOCIAL PROTECTION

JANUARY 2003
An electronic version of the paper may be downloaded
- from the SSRN website: www.SSRN.com
- from the CESifo website: www.CESifo.de




\title{
AGEING AND FISCAL IMBALANCES ACROSS GENERATIONS: CONCEPTS OF MEASUREMENT
}

\begin{abstract}
In the literature, several approaches have been taken to measure the impact of demographic ageing on public pension schemes, with particular attention being paid to potential fiscal imbalances across the generations involved in demographic transition. In this paper, we review three of these measures - viz., "net pension liabilities" and "general government fiscal balances" as suggested by the OECD, as well as "generational accounting" in the AuerbachKotlikoff tradition. We show how these approaches are related to each other by the general idea that unfunded pensions create an implicit public debt, and we discuss the problems involved in applying and interpreting them in a real-world context. In addition, we suggest the "implicit tax" entailed in public pensions as a further concept for measuring the intergenerational distribution of burdens arising in ageing populations. The notion of an implicit tax is straightforward from simple pension algebra; it is easy to interpret in a theoretical perspective; and it can be introduced to various kinds of applied work using micro-level data.
\end{abstract}

JEL Classification: H55, E62, D63.

Keywords: demographic ageing, public pensions, fiscal policy, inter-generational redistribution, measurement.

\author{
Robert Fenge \\ Ifo Institute for Economic Research \\ Poschingerstrasse 5 \\ 81679 Muenchen \\ Germany \\ fenge@ifo.de
}

\author{
Martin Werding \\ Ifo Institute for Economic Research \\ Poschingerstrasse 5 \\ 81679 Muenchen \\ Germany \\ werding@ifo.de
}




\section{Introduction*}

The process of ageing that is going on in many industrialised countries leads to imbalances in the distribution of burdens across generations. The inter-generational distribution is affected through many channels. Nonetheless, the systems of old-age provision can easily be detected to be one of the most important channels for ageing placing higher burdens on younger generations. In turn, demographic ageing will exert substantial pressure on current public pension systems during the years to come.

Problems are by far less pressing, though not immaterial, if future pension entitlements are backed by some way of pre-funding. This is particularly true if funds are invested in the market and if debtors belong to the private sector. Under any other arrangement, future claims on public pensions must be considered a distinct type of unfunded government debt which sometimes may be less visible than usual forms of public liabilities, but which can become acute very rapidly as population ages.

The burden of this debt is an implicit one in the case of public pension schemes that are run on a pay-as-you-go (PAYG) basis. (Note, by the way, that PAYG financing is clearly a domain of the public sector, with huge problems of credibility preventing private agents or corporations from setting up pension plans that are openly unfunded. ${ }^{1}$ ) Ageing population then implies that, in order to maintain the budget of the public pension scheme in equilibrium, either contribution rates have to be increased or benefit levels have to be re-considered. The latter option - which is equivalent to effectively wiping out part of the pension liabilities - may be the most prominent aspect by which the debt implied in PAYG pension schemes differs from explicit public debt.

Things are not much different in the case of funded schemes where investment is mainly in government bonds - for instance, because the funds themselves are managed by a public body. If population ages and net investment of these funds becomes negative, at least part of the debt needs to be paid off. This implies that general taxation needs to be expanded in order to redeem outstanding bonds (or, given that default is not an option in this case, other types of public expenditures have to be cut down correspondingly). At closer inspection, public pension schemes that are built on explicit government debt and, hence, on future tax revenues or taxing capacities effectively turn out

\footnotetext{
* The present paper forms part of a larger research project which was generously supported by the Economic and Social Research Institute (ESRI) of the Japanese Government. Of course, all errors and omissions are ours.

1 In most countries, legal constraints add to these endogenous restrictions that are inherent in market interactions.
} 
to be of an "implicit" pay-as-you-go variety. Problems and potential solutions for schemes of this type are therefore fully captured in the following. ${ }^{2}$

Around the world, most public pension systems are based on PAYG financing in an explicit way. ${ }^{3}$ Together with the above considerations regarding "implicit" PAYG systems this implies that, as the relevant baseline, we may safely confine our attention to pension schemes that are both public and openly unfunded when assessing the intergenerational distribution of burdens associated with ageing populations. ${ }^{4}$

The basic problem is simple. Demographic ageing implies that the old-age dependency ratio - commonly defined to be the ratio of elderly people (aged 65 and over) over working-age population (aged 15 through 64$)^{5}$ - is increasing over time. For a broadbased public pension scheme this fundamental trend is very likely to carry over to increases in the so-called "system dependency ratio" - the ratio of pensioners over active contributors. Lower unemployment, higher participation rates (of women and elderly workers, for instance), or discretionary extensions of the insured population may help in slowing down this process. But the effects of rapid ageing, as is projected to take place in many industrialised countries, will rarely be off-set by these changes in economic conditions, individual behaviour, or legal institutions.

If the pension scheme is purely pay-as-you-go the annual budget must have been balanced at the outset of the ageing process. Now, as system dependency starts to rise current contributions tend to fall short of current pensions. If, as a response, the level of individual pensions is kept constant, while contribution rates are driven up, younger age-cohorts will be hurt. Alternatively, if contribution rates are constant and the benefit level is reduced old generation will be negatively affected. ${ }^{6}$ Note that in practice, these two types of strategies are not perfectly symmetric. What must be taken into account is

2 Here, we leave aside all issues related to the efficiency of fund management which may also be of high importance for funded pension schemes that are publicly organised (rather than publicly mandated or entirely left to private sector arrangements).

3 For many years the Japanese public pension scheme was one of the most prominent exceptions worth mentioning (Barr 1992, 772). In the case of Japan, however, our description of "implicit" PAYG financing applies. - Things are different in a number of countries that have embarked more recently on pension reforms aiming at funded pensions in conjunction with a privatisation of pension plans (see Queisser 1998 for a survey). Strategies of this kind are meant to avoid exactly those problems that we want to discuss here.

4 For a discussion of how private, funded systems are affected by large-scale population ageing, see Brooks (2000).

5 Other definitions, like population aged $60+$ per population aged 20-59, may be more suited to capture actual patterns of labour force attachment in many industrialised countries. However, the main difference between these alternative measures relates to the level of old-age dependency, not to its trend.

6 In this case, younger people will face lower contributions and lower benefits (if the demographic tension does not vanish somehow). On net present value terms this may nevertheless be an advantage. See the parallel paper by Fenge and Werding (2003) for many illustrations. 
that - at least, prior to recent reforms - most public pension systems have been, or still are, defined (level of) benefit schemes. Given that, for projections based on current policies the most likely outcome to obtain is that ageing will lead to higher burdens falling on young and future generations. Only to the extent that the current benefit level is partially adjusted during this process part of the burden will be shifted to current pensioners and older workers. In any case, the relatively low burden placed on age cohorts that have already passed away can by no means be altered. ${ }^{7}$

Several approaches have been developed in order to measure the imbalances of burden sharing between different generations that arise from population ageing (see table 1 for an overview). The present paper is mainly devoted to laying out the differences and common features of all these approaches against the background of the simple algebra of unfunded pension schemes, explaining their relative merits and disadvantages in analysing the problems of ageing for existing pension systems.

One major distinction is that between concepts which measure the consequences of ageing for pension funds (and public finances in general) on an aggregate level vs. concepts which highlight effects that show up on an individual level, i.e. for representative agents belonging to both current and future age cohorts. Another distinction is that between concepts which concentrate on pension systems alone and concepts which expand the view to general government expenditure, where old-age protection is just one budget item which can be affected by population ageing. As a result, we have four major classes of concepts that can be applied to measuring the fiscal stance of public (pension) budgets in the presence of projected demographic change (see again table 1).

A few years ago the OECD has started to calculate "Net pension liabilities" (van den Noord and Herd 1993; 1994) based on long-term projections for revenues and expenditures of public pension systems. Building on this type of work, the OECD has also developed the concept of "General government fiscal balances" (Leibfritz et al. 1995; Roseveare et al. 1996), extending the idea of measuring implicit public liabilities to a larger set of fiscal activities. Another widely-used measure for the effects of public finance on inter-generational distribution is given by the method of "Generational accounting" (Auerbach et al. 1991; 1999), again comprising virtually all public budget items and the way they affect different generations. European economists have provided another tool for analysing the intergenerational effects of old-age security systems in a very simple, but illustrative, way which they call the "Implicit tax" entailed in public pension schemes (Sinn 1997; Thum and Weizsäcker 2000).

\footnotetext{
The latter observation is trivial of course, though in some sense detrimental. We will see in the following that the effects of unfunded pension schemes for inter-generational distribution are partly inherited from past decisions that cannot be called off.
} 
Table 1: Inter-generational imbalances in public (pension) budgets: concepts of measurement

\begin{tabular}{|c|c|c|c|}
\hline & \multicolumn{2}{|c|}{ Concepts looking at... } \\
\hline & & macro-level effects & micro-level effects \\
\hline 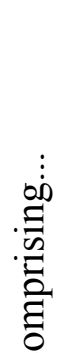 & 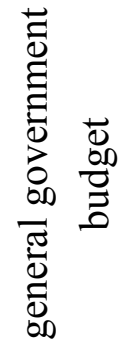 & $\begin{array}{c}\text { "General } \\
\text { government } \\
\text { fiscal balances" }\end{array}$ & $\begin{array}{l}\text { "Generational } \\
\text { Accounting" }\end{array}$ \\
\hline 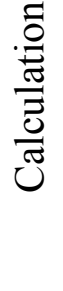 & 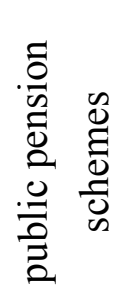 & $\begin{array}{l}\text { "Net pension } \\
\text { liabilities" }\end{array}$ & $\begin{array}{c}\text { "Tax implied } \\
\text { in public pension } \\
\text { schemes" }\end{array}$ \\
\hline
\end{tabular}

All these approaches are of course related to each other. At the same time, each of them has its particular features. In a series of parallel papers (Fenge et al. 2002; Fenge and Werding 2003), we employ the concept of the tax implied in unfunded pension schemes for simulations and empirical work. Thus, the current paper is mainly setting the stage for further efforts, providing part of the methodological underpinnings needed to move to applied work. In order to do so, we now will briefly introduce and discuss each of the above concepts in some more detail. As a baseline, we will first of all spell out the composition and determinants of the implicit - or, at times, explicit - debt involved in public pension schemes.

\section{The baseline: the debt implied in public pension schemes}

In unfunded pension schemes, current contributions are distributed to current pensioners. At the same time, contributors accumulate entitlements for future pension benefits which will become effective upon their retirement. By definition, no reserves are held in order to fund for these open liabilities. Instead, they will be financed by future contribu- 
tions which, in turn, give rise to further pension entitlements within an overall system of revolting loans.

At each point in time, the implicit debt of unfunded pension schemes is therefore given by the present value of $(a)$ outstanding claims of current old-age pensioners and (b) future pension benefits of the active population which have been acquired by their past and current contributions. Future contributions of those who are currently active (or those who enter activity in the following periods of time) will pay off part ( $a$ ) and add to part $(b)$ of the above definition. In a stationary state of the world, these contributions will be neutral with respect to the implicit debt on absolute terms. In a scenario with steady state growth, they will be neutral with respect to the relative size of the debt - if compared to GDP or to the total payroll, for instance, and given proper discounting.

Consider a series of successive "overlapping" generations, numbered by the period $t \in\{0,1,2, \ldots\}$ in which they enter working life. Each individual in generation $t$ lives for two periods of economic activity and one additional period of retirement. For convenience, labour supply of younger and older workers is assumed to be fixed and normalised to unity, labour supply of pensioners is zero. Let $w_{i, t}$ denote the wage rate accruing to individual $i \in\left\{1,2, \ldots N_{t}\right\}$ at date $t$. During her working life, each individual faces a rate $\theta_{t}$ of contributions to be made to the public pension scheme which is assumed to be invariant over $i$ in a given period of time, but may be different at $t+1$. Upon retirement she will be entitled to receive a pension $p_{i, t+2}\left(\theta_{t} w_{i, t}, \theta_{t+1} w_{i, t+1}\right)$.

In reality, $p(\cdot)$, which links the amount of pension benefits accrued to contributions made in each period of economic activity, can be a very odd function. For instance, it can be zero until contributions have been made for a minimum qualification period of several years. Afterwards, it may jump to a full flat-rate amount of pensions immediately; it may be linear in $\theta_{t} w_{i, t}$ or $w_{i, t}$; or it may be related to contributions, wages, or life-time wage profiles in many other ways.

Within the context of this stylised setting ${ }^{8}$ quite a number of useful calculations are possible. For instance,

$$
W_{t}=\sum_{N_{t-1}} w_{i, t}+\sum_{N_{t}} w_{i, t} \quad \text { and } \quad \Theta_{t}=\theta_{t} W_{t}=\theta_{t}\left[\sum_{N_{t-1}} w_{i, t}+\sum_{N_{t}} w_{i, t}\right]
$$

8 Extension to a more realistic structure of periods is straightforward. Allowing for an annual structure of the model with variable length of an individual's working life would result in rather complex equations, removing much of the clarity of the following calculations. A continuous-time notation, however elegant, would not be fully fitting to the way in which public pension schemes are actually managed or to the way in which annual budgeting procedures are reflected in most long-run projections. 
are the total payroll garnered in period $t$ and total revenue from period $t$ contributions, respectively. Defining $w_{t}$ to be $W_{t} /\left(N_{t-1}+N_{t}\right)-i . e$, the average wage rate of period $t$ - we may also write these aggregates as

$$
W_{t}=\left(N_{t-1}+N_{t}\right) w_{t} \text { and } \Theta_{t}=\theta_{t}\left(N_{t-1}+N_{t}\right) w_{t} .
$$

In an unfunded pension scheme, total contributions must equal total benefits paid out during the same period of time,

$$
P_{t}=\sum_{N_{t-2}} p_{i, t}=N_{t-2} p_{t}
$$

where $p_{t}$ is the average pension benefit.

From an individual's perspective, life-time income is given by $w_{i, t}+R_{t+1}^{-1} w_{i, t+1}$, where $R_{t+1}=1+r_{t+1}$ is the interest factor and $r_{t+1}$ is the interest rate used for discounting (past or) future amounts to present values of period $t$. Life-time contributions therefore are $\theta_{t} w_{i, t}+R_{t+1}^{-1} \theta_{t+1} w_{i, t+1}$. Relating the present value of pension benefits, $R_{t+1}^{-1} R_{t+2}^{-1} p_{i, t+2}$, to life-time contributions, one may calculate the internal rate of return to contributions made to the pension scheme, etc. ${ }^{9}$

Here, the most important thing to note is that in our simple framework the debt implied in unfunded pension schemes is given by

$$
I D_{t} \equiv R_{t+1}^{-1} p_{t+1}\left(\theta_{t-1} w_{t-1}, \theta_{t} w_{t}\right) N_{t-1}+R_{t+2}^{-1} R_{t+1}^{-1} p_{t+2}\left(\theta_{t} w_{t}\right) N_{t}
$$

if evaluated for period $t$. Consequently, the ratio of implicit debt over total wage income - representing the current size of the future tax base available for funding $I D_{t}-$ is

$$
d_{t} \equiv \frac{I D_{t}}{W_{t}}=\frac{R_{t+1}^{-1} p_{t+1}\left(\theta_{t-1} w_{t-1}, \theta_{t} w_{t}\right) N_{t-1}+R_{t+2}^{-1} R_{t+1}^{-1} p_{t+2}\left(\theta_{t} w_{t}\right) N_{t}}{\left(N_{t-1}+N_{t}\right) w_{t}}
$$

It is easy to see that the size of $I D_{t}$ is mainly determined by the number of active contributors, the level of outstanding pension benefits, and the interest rate, with

$$
I D_{t}=I D(\underset{+}{N}, \underset{+}{N}, r)
$$

The relative burden incurred through $I D_{t}$ is also dependent on the "replacement rate" $p / w$, i.e. on the level of future benefits in proportion to current or future wages. In

9 We will go into these details later on, also showing how they interact with the periodic pay-as-you-go constraint for the overall system. See section 2.4 . 
turn, the benefit level depends on the rules that govern the link between pensions and wages in general and, more specifically, on the way pensions are indexed from period $t$ to later periods of time.

Surprisingly, in the context of population ageing no general conclusions are possible regarding changes in the size of the implicit debt, neither on absolute nor on relative terms. For more clear-cut results to obtain, more specific assumptions would be required on how labour productivity and current wages will respond to large-scale population ageing. If increasing life-expectancy and lower fertility rates come about as stable, longterm trends - implying that the average age of overall population and working-age population is constantly increasing - then $I D_{t}$ and $d_{t}$ can move in either direction. If upward and downward swings in fertility (i.e., a transitory "baby boom") add to these long-term shifts the implicit debt is very likely to rise as a percentage of current wage income as the age-cohorts of the "baby boomers" are approaching retirement. Nonetheless, the size of $I D_{t}$ and $d_{t}$, or their development over time, are no good indicators for the impact of ageing on public pension schemes.

Whatever the precise pattern of population ageing, it is however clear that the burden falling on individual contributors gets the larger, the higher the prospective ratio of old-age dependency (or "system dependency") in subsequent periods of time. If $N_{t}$, $N_{t+1}$ and $r$ are basically given, then one way of solving these problems is in manipulating $p_{t+1}$ and $p_{t+2}$ in order to reduce $I D_{t}$. The main alternative is to leave $I D_{t}$ unchanged, necessitating adaptations in $\theta_{t+1}$ and $\theta_{t+2}$, as we have already seen. In any case, combining a large number of assumptions regarding fundamental demographic trends, economic environment, individual behaviour, and actual policy choices one can obtain projections for the future development of $\left\{P_{x}, \Theta_{x}\right\}, x \in\{t+1, \ldots\}$. Building on these projections, the growing tension between future pension claims and revenues can be measured in different ways.

\section{Concepts of measurement}

Since the late 1970s it has become apparent that in most industrialised countries the downward swing in fertility rates is more than a temporary phenomenon and that lifeexpectancy is going on to rise without any upper limit coming into sight. On a national level, discussions about the impact of ageing on existing public pension schemes may have started at an early stage. On an international level, the general discussion was opened only in the late 1980s, when organisations like the OECD or the World Bank published major reports on the prospective "old age crisis" ( $c f$., for instance, Hagemann 
and Nicoletti 1989; World Bank 1994). These publications triggered an intense discussion on how to avert the imminent crisis. The first step to take, however, was to analyse the process of ageing more carefully and to devise useful instruments for measuring the potential problems arising for current pension schemes. As mentioned before, several concepts have been suggested.

\subsection{Net pension liabilities}

In an influential paper published by the OECD's Economics Department, van den Noord and Herd (1993) developed a conceptual framework for estimating "net pension liabilities" and applied it to the seven major OECD economies. ${ }^{10}$ Essentially, the concept captures the present value of current and future pension entitlements, net of existing assets and future contributions. The estimates are based on rather strong and simplifying assumptions, as well as on very simple simulation models - all of which has been improved upon in subsequent studies. ${ }^{11}$

The implicit debt of existing pension schemes, as defined in the previous section, is incorporated into the calculations as the "present value of accrued rights" (minus financial reserves, if any). Based on projections for the future development of public pension schemes, the current debt is reduced by the present value of future contributions, but increased by the present value of future entitlements that are a result of these new contributions. Formally, the time horizon of the calculations involved is extended from the present period of time to some $t+T, T>2$, as far as pension benefits are concerned, and to $t+T-2$ with regard to future contributions. Thus, if the level of pensions or contribution rates were adjusted in period $t+1$ etc. to meet the periodic pay-as-you-go budget constraint, then"net pension liabilities" $\left(N P L_{t}\right)$ at date $t$ would turn out to be

$$
\begin{aligned}
N P L_{t} \equiv & R_{t+1}^{-1} P_{t+1}+R_{t+1}^{-1} R_{t+2}^{-1} P_{t+2}+\ldots+R_{t+T-1}^{-1} \ldots R_{t+1}^{-1} P_{t+T-1}+ \\
& +R_{t+T}^{-1} \ldots R_{t+1}^{-1} p_{t+T}\left(\theta_{t+T-2} w_{t+T-2}\right) N_{t+T-2}- \\
& -R_{t+1}^{-1} \mathrm{~T}_{t+1}-R_{t+1}^{-1} R_{t+2}^{-1} \mathrm{~T}_{t+2}-\ldots-R_{t+T-2}^{-1} \ldots R_{t+1}^{-1} \mathrm{~T}_{t+T-2}- \\
= & R_{t+T-2}^{-1} \ldots R_{t+1}^{-1} I D_{t+T-2} .
\end{aligned}
$$

10 I.e., the U.S., Japan, Germany, France, Italy, the UK, and Canada. For an in-depth discussion of the methodology adopted see also van den Noord and Herd (1994).

11 Most recently, the $\operatorname{OECD}(1998 ; 2000 ; 2001$, chapter 4) has run a series of follow-up studies to a project called "Maintaining prosperity in an ageing society". This time, national governments and experts from about 30 OECD countries were involved in order to come up with more accurate projections regarding national pension systems. (For the German contribution, see Werding and Blau 2002.) 
Since, by assumption, $P_{t+1}=\mathrm{T}_{t+1}$ etc., the only two terms that do not cancel out in this definition are $R_{t+T-1}^{-1} \ldots R_{t+1}^{-1} P_{t+T-1}=R_{t+T-1}^{-1} \ldots R_{t+1}^{-1} p_{t+T-1}\left(\theta_{t+T-3} w_{+T t-3}, \theta_{t+T-2} w_{t+T-2}\right) N_{t+T-3}$ and $R_{t+T}^{-1} \ldots R_{t+1}^{-1} p_{t+T}\left(\theta_{t+T-2} w_{t+T-2}\right) N_{t+T-2}$. Assuming continuous adjustments for the pension budget to be balanced at each point in time, the net pension liabilities are thus nothing else but the amount of implicit debt at date $t+T-2$ discounted to current values. (Note that, if $T=2, N P L_{t}=I D_{t}$.)

When calculating net pension liabilities, however, the more interesting part of the exercise is to rely on status-quo projections using current policy parameters for both benefit levels and contribution rates given future demographic trends. In this case, benefits and revenues need not cancel out for future periods of time and estimated net pension liabilities can be substantially larger than they are according to the above formula: $^{12}$

$$
\begin{aligned}
N P L_{t}= & R_{t+1}^{-1} p_{t+1}\left(\theta_{t-1} w_{t-1}, \theta_{t} w_{t}\right) N_{t-1}+R_{t+1}^{-1} R_{t+2}^{-1} p_{t+2}\left(\theta_{t} w_{t}, \theta_{t} w_{t+1}\right) N_{t}+\ldots+ \\
& +R_{t+T}^{-1} \ldots R_{t+1}^{-1} p_{t+T}\left(\theta_{t} w_{t+T-2}\right) N_{t+T-2}- \\
& -R_{t+1}^{-1} \theta_{t}\left(N_{t}+N_{t+1}\right) w_{t+1}-\ldots-R_{t+T-2}^{-1} \ldots R_{t+1}^{-1} \theta_{t}\left(N_{t+T-3}+N_{t+T-2}\right) w_{t+T-2}
\end{aligned}
$$

Here, we concentrate on the case where the level of pensions is given - for instance, by a wage indexation rule - and contributions are kept constant at the period $t$ level. As population ages, this will imply that the pension budget runs a deficit which is increasing over time. The present value of debt that will be accumulated is given by $N P L_{t}$ which, for illustrative purposes, can also be expressed as a percentage of aggregate earnings or GDP, both for present and future periods of time. In any case, the amount of net pension liabilities can now be regarded as an important indicator for the long-run sustainability of existing pension systems in the case that policy is unchanged. In addition, policy simulations are possible which show how, and by how much, several types of adjustments will affect a given system's sustainability in a beneficial way.

In the 1993 paper by van den Noord and Herd, for example, the results for the "status-quo" scenario are confronted with four alternative policy regimes where $(a)$ contributions are increased as necessary to match the periodic pay-as-you-go constraint, (b) contributions are increased in the short and medium term to exceed current pension expenditure, thus building up (transitory) funds for financing future pension entitle-

12 See Holzmann et al. (2000) for a clarifying discussion of how "net pension liabilities" - or, as it is termed there, the "open system liability" - is composed $(a)$ by the current implicit debt, $(b)$ by an actuarial deficit of future contributions of current workers over future pensions that are due to these contributions, and $(c)$ by an actuarial deficit of contributions of future generations over pensions for future generations. 
ments, $(c)$ the level of benefits is reduced by means of a lower indexation of pensions, and (d) the average age of retirement is increased. ${ }^{13}$ In a sense, the comparison between these different scenarios and their differential impact on current and future generations is much more informative than the baseline scenario alone. If taken in isolation, the results obtained for the status-quo scenario are hard to assess. Also, the effective balance of future contributions over future benefits predicted for the status quo case is surprisingly low (van den Noord and Herd 1993, table 7). ${ }^{14}$ In the majority of countries, the projected amount of $N P L_{t}$ is therefore very close to the estimate given for $I D_{t}$.

To sum up, net pension liabilities extend the notion of an implicit debt - i.e., of accrued rights that are open at date $t$ - to a longer time-horizon, taking into account potential future deficits of revenues over expenditures which may arise in unfunded pension schemes given current policy parameters. Thus, they offer a concept of measurement which is straightforward from the simple algebra of PAYG financing and is highly suited to capture the impact of ageing on current pension systems on an aggregate level. At the same time, it is less clear how these hidden liabilities will be perceived by current and future individuals and, in particular, how they may affect individual decisions.

\subsection{General government fiscal balances}

One way of extending the analysis of unfunded pension liabilities is to integrate the results into more conventional approaches to assessing fiscal policies. Basically, this is the road taken by Roseveare et al. (1996) in their study on "Ageing populations, pension systems and government budgets". The methodology developed there, building on an earlier study by Leibfritz et al. (1995), is still applied by the OECD in a current project on the fiscal consequences of ageing. ${ }^{15}$ At the same time, this approach allows to take into account other channels through which the inter-generational distribution can be affected in ageing populations. For instance, public health care is regarded another prominent source of inter-generational imbalances that arise as a consequence of increasing old-age dependency.

13 The latter option can be interpreted as another way of manipulating the effective level of pension benefits in a less visible fashion. The present value of individual life-time pensions is clearly reduced be extending the working-age period. At the same time, current living standards of old-age pensioners are not affected.

${ }^{14}$ It should be stressed that this is not the outcome of openly cutting off the inter-temporal links between contributions and benefits at some point in the future. Rather, it reflects the fact that demographic projections that were available at that time underestimated both the future rise in life-expectancy and the persistence of low fertility in most industrialised countries.

15 See footnote 11. At an early stage, the approach has also been adopted by the IMF, for example in Chand and Jaeger (1996). 
Essentially, what Roseveare et al. (1996) are doing is the following. They rely on explicit forecasts for the development of pension schemes and public health expenditures for 20 OECD countries, estimating the accumulating deficit of current contributions over current benefits for alternative policy scenarios. Since inter-temporal linkages between contributions (or taxes) and benefits are weak in most public health care systems, they drop the notion of an implicit debt in terms of accrued rights also for public pension systems. Instead, they simply look at periodic flows of both revenues collected and expenditures to be made.

Concentrating on the public pension branch of general government fiscal activities, the impact of ageing on public finances then shows up in the net present value of "accumulated deficits" (here called $A D_{t}$ ) in future periods of time - for instance, ranging from period $t+1$ to $t+T-2$ :

$$
\begin{aligned}
A D_{t} \equiv & R_{t+1}^{-1} P_{t+1}+\ldots+R_{t+T-2}^{-1} \ldots R_{t+1}^{-1} P_{t+T-2}- \\
& -R_{t+1}^{-1} \theta_{t}\left(N_{t}+N_{t+1}\right) w_{t+1}-\ldots-R_{t+T-2}^{-1} \ldots R_{t+1}^{-1} \theta_{t}\left(N_{t+T-3}+N_{t+T-2}\right) w_{t+T-2}
\end{aligned}
$$

In a first round of status-quo projections, estimates for future revenues $\Theta$ are based on present contribution rates $\theta_{t}$ (or, at least, on policies that are currently enacted). Again, alternative policy scenarios can then be considered against this benchmark.

Adding other general government budget items, like public health care, yields

$$
\begin{aligned}
A D_{t}= & R_{t+1}^{-1}\left(P_{t+1}+E_{t+1}\right)+\ldots+R_{t+T-2}^{-1} \ldots R_{t+1}^{-1}\left(P_{t+T-2}+E_{t+T-2}\right)- \\
& -R_{t+1}^{-1}\left(\theta_{t}+\vartheta_{t}\right)\left(N_{t}+N_{t+1}\right) w_{t+1}-\ldots-R_{t+T-2}^{-1} \ldots R_{t+1}^{-1}\left(\theta_{t}+\vartheta_{t}\right)\left(N_{t+T-3}+N_{t+T-2}\right) w_{t+T-2},
\end{aligned}
$$

where $E_{t}$ is public health expenditure (or any other type of public expenditure not related to the pension system) and $\vartheta_{t}$ is the corresponding rate of contributions or taxes.

A more intuitive way of presenting these results is not to discount periodic (e.g., annual) deficits to period $t$, adding up these net present values. Instead, for each of the future periods of time, $P_{t}-\Theta_{t}$ can be interpreted as the differential impact of ageing on the general government primary fiscal balance. ${ }^{16}$ Consequently, in all subsequent periods of time there will be a differential impact on the general government total balance, now including interest payments. Finally, combining higher current deficits and compound interest leads to an estimate for the differential impact on accumulated public debt exerted by the age-related trends in public expenditure.

16 In other words, increasing deficits in the pension (and public health care) system reduce an eventual surplus of primary revenues over primary expenditure or add to the current primary deficit. 
To be sure, the final result of these calculations is nothing but $R_{t+T-2} \ldots R_{t+1} A D_{t}$, $T>2$ (or a corresponding time series for variable $T$ ). But if current deficits and accumulated debt shall be expressed as a percentage of current GDP, as is conventionally done in analyses of general government budgets, the discounted value of $A D_{t}$ per period $t$ income would clearly underestimate the burden of ageing on public finances. The reason is that the rate used for discounting future deficits, $r$, will generally exceed the growth rate of wages or aggregate output. Therefore, relative measures that are more appropriate than $A D_{t} /\left(N_{t-1}+N_{t}\right) w_{t}=A D_{t} / W_{t}$ or $A D_{t} / G D P_{t}$ are given by

$$
R_{t+T-2} \ldots R_{t+1} A D_{t} /\left(N_{t+T-3}+N_{t+T-2}\right) w_{t+T-2}
$$

or

$$
R_{t+T-2} \ldots R_{t+1} A D_{t} / G D P_{t+T-2} \text { etc. }
$$

Finally, calculations on general government fiscal balances of the above type can be completed by plugging the differential impact of ageing on current deficits and debt into a benchmark scenario for the levels of deficits and debt. As a rule, this is done holding constant (as a percentage of GDP) all other types of public revenues and expenditure, i.e. taking as given the primary deficit (or surplus) in the baseline year of the projections. In this case, the resulting point estimates for future ratios of total deficit and accumulated debt over current GDP are highly dependent on the initial situation or on any alternative assumptions made with respect to the benchmark scenario.

With a favourable fiscal stance in the baseline year, for instance, the debt ratio may well become negative at some point in time in the benchmark scenario - i.e. when the impact of ageing is disregarded. This trend will be slowed down or even reverted if the pension system is taken into account. Using another year as the baseline, or looking at a different country, the impact of ageing on pensions may rather boost an explosion of public debt that is already increasing in the benchmark case. To some extent, this is already apparent in the results originating from the 1996 OECD project ( $c f$. Roseveare $e t$ al. 1996, figure 6). It is highly evident from the results of current follow-up studies ${ }^{17}$ which are based on more recent national fiscal policies. In many cases the situation of public budgets has substantially improved around the year of 2000 for reasons that are not related to long-term demographic ageing or to far-sighted policy responses. In particular, if results are to be compared across countries, all that matters is therefore included in the intermediate results regarding the differential impact of pensions and health expenditure on public finances. Given that these estimates for changes in current

17 For instance, see again Werding and Blau (2002). 
deficits and accumulated debts are reliable, they will be relevant under whatever fiscal policies that are pursued in other branches of government finance.

If compared to the concept of net pension liabilities, calculating the impact of ageing on general government fiscal balances offers another way of measuring effects that are situated at the macro-level. Now, attention shifts away from a particular focus on public pensions, guided by the simple theory of old-age provision, and towards the direction of conventional budget analyses. One of the drawbacks involved in this move is that the effects for public pension schemes are somewhat diluted by combining them with those for other budget items and by integrating them into arbitrary benchmark scenarios for the future development of general government finances. If projections concentrate on changes in deficits and debts that are due to demographic ageing, rather than aiming at point estimates for future levels, they may nonetheless be informative for politicians who are in charge of periodic budgeting procedures. As in the case of net pension liabilities, it is less clear how this kind of information about fiscal aggregates may be relevant for individuals.

Finally, while the way general government fiscal balances are calculated is closely connected to widely-used approaches to analysing fiscal policies, introducing the prospective impact of ageing to this kind of work, important pieces of information are lost. When estimating future fiscal balances it is largely ignored that future contributions (and taxes) are not just covering future pension claims (and other types of benefits) but at the same time give rise to new entitlements that go beyond the time horizon of any projection for $A D_{t}$. In other words, inter-temporal links between contributions and benefits that are an essential ingredient in most public pension schemes are cut off at the end of the projection horizon. The character of accrued rights as an unfunded liability is therefore ignored, thus potentially underestimating the fiscal burden of ageing by a considerable margin.

\subsection{Generational accounting}

A well-known instrument designed to capture exactly those future liabilities that are hidden in conventional budget analyses has been suggested by Auerbach et al. (1991) under the name of "generational accounting". Again, virtually the whole range of fiscal activities of the state is to be condensed into one set of indicators. But now the notion of an implicit public debt is incorporated explicitly. At the same time, all levels and trends that are expected to show up in the aggregate are broken down to an individual level, i.e. to results that are relevant for representative agents in different age cohorts.

Generational accounts are given by a series of fiscal balances for individuals in each of the successive generations under consideration, based on the net present value 
of all present and future taxes and contributions $v s$. all present and future benefits which are open at date $t$. In our basic model, examples are

$$
\begin{aligned}
G A_{t}^{t-2} & \equiv-p_{t}\left(\theta_{t-2} w_{t-2}, \theta_{t-1} w_{t-1}\right)-e_{t} \\
G A_{t}^{t-1} & \equiv\left(\theta_{t}+\vartheta_{t}\right) w_{t}-e_{t}-R_{t+1}^{-1}\left(p_{t+1}\left(\theta_{t-1} w_{t-1}, \theta_{t} w_{t}\right)+e_{t+1}\right) \\
G A_{t}^{t} & \equiv\left(\theta_{t}+\vartheta_{t}\right) w_{t}-e_{t}+R_{t+1}^{-1}\left(\left(\theta_{t}+\vartheta_{t}\right) w_{t+1}-e_{t+1}\right)-R_{t+2}^{-1} R_{t+1}^{-1}\left(p_{t+2}\left(\theta_{t} w_{t}, \theta_{t} w_{t+1}\right)+e_{t+2}\right) \\
G A_{t}^{t+1} & \equiv R_{t+1}^{-1}\left(\left(\theta_{t}+\vartheta_{t}\right) w_{t+1}-e_{t+1}\right)+R_{t+1}^{-1}\left(E D_{t+1}+I D_{t+1}\right) N_{t+1}^{-1}
\end{aligned}
$$

where in $G A_{t}^{t-2}$ etc. lower indices refer to the time period of measurement and upper indices denote generations or age-cohorts; $e_{t}$ is the per-capita amount of other general government expenditure in period $t$; and $E D_{t}$ is explicit government debt. Again we concentrate on a scenario where current policy governs the time paths for $\left\{p_{x}, e_{x}\right\}$, $x \in\{t+1, \ldots\}$, as well as the levels of $\left\{\theta_{t}, \vartheta_{t}\right\} .^{18}$

The fact that for older generations $G A_{t}$ is, or is very likely to be, negative - indicating a surplus of pensions and benefits to be received over contributions and taxes to be made - is not really informative. Since all fiscal activities prior to period $t$ are ignored here, this is mainly a matter of inter-temporal shifts of resources which have been deliberately designed, rather than being a result of inter-generational redistribution that is brought about voluntarily or involuntarily by pursuing any course of fiscal policy. Results that are more interesting are therefore given $(a)$ by $G A_{t}^{t}$, which represents the fiscal balance of the generation who enters the stage of public finances ("is born") in the period when accounts are set up, and (b) by $G A_{t}^{t+1}$, which accounts for the situation of (all) future generations.

The most important thing to note is that $G A_{t}^{t+1}$ incorporates explicit as well as implicit government debt in terms of a per-capita amount falling on generation $t+1$. The calculation of generational accounts is based on the general idea that an inter-temporal budget constraint is imposed on the overall system of general government finance. The simple message is that all present and future benefits have to be paid for by someone. If the corresponding burden is not placed on present generations, it will inevitably fall on those who are currently unborn. In the above case, $E D_{t+1}$ and $I D_{t+1}$ will be influenced by the choice of $\{\theta, \vartheta\}$ for period $t+1$. If these parameters were adjusted to keep the budget balanced and, eventually, to fund for the implicit debt and/or to pay off the ex-

18 In addition, we assume that old-age pensions are not subject to general taxation and we abstract from benefits that accrue prior to working-age. The model can be easily adapted to capture alternative policy regimes and it can be extended to cover generation $t+2$ if generation $t+1$ receives $-e_{t}$ during childhood. 
plicit debt, then the situation of future generations would be more favourable - at the expense of generations who are currently alive.

Generational accounting has now made its way around the world, provoking numerous studies on individual countries, including extensive policy simulations. In addition, a number international research projects have been launched in order to make results comparable across different countries (see, for example, Kotlikoff and Leibfritz 1999; or Kotlikoff and Raffelhüschen 1999). The scope of generational accounting exercises has expanded a lot in the sense that a growing number of single budget items are disaggregated with respect to their incidence over a typical life cycle and can be allocated to either contributors or beneficiaries on an individual level. ${ }^{19}$ Following initial enthusiasm, however, the role of generational accounts in both policy-oriented research and actual political decision-making may now be declining again.

The method of setting up generational accounts has been criticised on several grounds. ${ }^{20}$ As a matter of fact, most of these criticisms apply to the other concepts discussed here as well. First of all, a lack of economic structure has been objected to generational accounting since the underlying models used for simulations are mostly not general-equilibrium and, more fundamentally, since the focus is on balances of financial transactions only. In other words, quite a number of endogenous responses to population ageing may be missing in the calculations. In addition, effects of inter-generational redistribution for individual or social welfare are not considered. ${ }^{21}$ Another major objection is that generational accounting has produced some confusion as to the important differences between explicit and implicit government debt which must not be overlooked - even if there are good reasons to have a closer look at the latter. ${ }^{22}$

In spite of these problems, generational accounting - as well as the other concepts developed for measuring inter-generational imbalances in current pension schemes and in fiscal policy as a whole - can be a very useful instrument. Still, two aspects should be mentioned which can be regarded as limiting the relevance of generational accounts if

19 Nowadays, generational accounts typically cover a wide range of revenues (i.e. all sorts of direct and indirect taxes, social security contributions, seigniorage, current deficits, etc.) and expenditure (e.g., spending on pension benefits, public health care, education, housing, infrastructure, other transfers and other general government consumption).

20 For an early example, see Haveman (1994).

21 For a modest defence against these obvious criticisms, see Fehr and Kotlikoff (1999).

22 See Franco (1995): as a rule, implicit pension liabilities are based on mandatory arrangements rather than on voluntary transactions; claims on public pensions cannot be traded; often, they are not defined on nominal terms and, given massive uncertainty about a number of relevant variables, cannot be determined unambiguously; last but not least, the amount of implicit debt is subject to discretionary choices to be taken by the debtor who can modify both the timing and level of pensions and other payments. 
compared to other concepts considered here. What makes it extremely difficult to set up generational accounts is that one has to deal with a wide range of fiscal activities, in each case aiming at sub-modules and projections that are both rich of details and consistent with all other branches of the model. When it comes to specific policy implications, however, it is again the single budget items one has to go into. In a sense, a lot of effort may have been wasted on this way. This can be regarded as an argument in favour of concepts that are more restricted in scope - for instance, concentrating on public pension schemes and on $I D_{t}$ alone. ${ }^{23}$ Secondly, the huge difference between the generational accounts $G A_{t}^{t}$ (for the last generation alive at date $t$ ) and $G A_{t}^{t+1}$ (for those "born" at $t+1$, including all explicit and implicit debt of period $t+1)$ does not really show the room that is left for manoeuvre. Certainly, someone has to pay the bill for any outstanding liabilities. But as generation $t$ has inherited an important part of $I D_{t}$ (and $E D_{t}$ ) from previous generations, they may as well pass on some portion of $I D_{t+1}$ to their successors. Ideally, the burden that is constituted by implicit pension debt can be distributed over an infinite number of age-cohorts - the only restriction being that the debt must not explode in finite time and that all transactions are sunk which took place prior to period $t$. This is an argument for searching another more flexible method of analysing $I D_{t}$, suited to demonstrate how each present and future generation may contribute to funding it.

\subsection{Implicit taxes}

The conclusion that there is a burden involved in any unfunded pension scheme once the system is matured is an obvious one. Certainly, no one should claim originality for defining this burden more precisely to be a tax which is implicitly levied on a given individual's life-time income. What may have been overlooked for quite some time, however, is that this notion of an implicit tax is extremely useful $(a)$ for understanding the general effects of pay-as-you-go pensions for the inter-generational distribution (Sinn 1997; 2000), ${ }^{24}$ and (b) for demonstrating the particular impact of ageing on individuals who belong to different age-cohorts (Weizsäcker and Thum 2000; Sinn and Werding 2000).

23 Clearly, the downside is that any links between the pension system and other branches of the general government budget may not be fully captured in this case. Examples are given by complicated rules with respect to net-wage indexation of pension benefits, injections into pension funds taken from general tax revenues, hidden cross-subsidies between the pension scheme and health care for the elderly, etc. In any of these cases, additional assumptions are needed that go beyond the narrow limits of making sensible projections for the pension system as such.

24 An earlier contribution has been made by Lüdeke (1988). To the best of our knowledge, he was the first to develop systematically the fiction of a tax on life-time income which is built in the pay-as-yougo mechanism. See also Homburg and Richter (1990). 
The tax entailed in unfunded pensions is simply given by the difference between life-time contributions and old-age pensions at an individual level, both discounted to net present values of some period $t$. In our stylised model, this leads to:

$$
\begin{aligned}
I T_{t}^{t-2} & \equiv R_{t-1} R_{t} \theta_{t-2} w_{t-2}+R_{t} \theta_{t-1} w_{t-1}-p_{t}\left(\theta_{t-2} w_{t-2}, \theta_{t-1} w_{t-1}\right) \\
I T_{t}^{t-1} & \equiv R_{t} \theta_{t-1} w_{t-1}+\theta_{t} w_{t}-R_{t+1}^{-1} p_{t+1}\left(\theta_{t-1} w_{t-t}, \theta_{t} w_{t}\right) \\
I T_{t}^{t} & \equiv \theta_{t} w_{t}+R_{t+1}^{-1} \theta_{t+1} w_{t+1}-R_{t+2}^{-1} R_{t+1}^{-1} p_{t+2}\left(\theta_{t} w_{t}, \theta_{t+1} w_{t+1}\right) \\
I T_{t}^{t+1} & \equiv R_{t+1}^{-1} \theta_{t+1} w_{t+1}+R_{t+2}^{-1} R_{t+1}^{-1} \theta_{t+2} w_{t+2}-R_{t+3}^{-1} R_{t+2}^{-1} R_{t+1}^{-1} p_{t+3}\left(\theta_{t+1} w_{t+1}, \theta_{t+2} w_{t+2}\right) \ldots
\end{aligned}
$$

Again, in $I T_{t}^{t-2}$ etc. lower indices refer to the time period of measurement, while upper indices denote generations or age-cohorts. In a sense, these implicit taxes are just partial generational accounts - now taking the pension system in isolation and not restricting the attention to cover present and future financial flows only. ${ }^{25}$

As with the implicit debt $I D$, defining $I T$ on absolute terms is not very instructive. Instead, one may consider the implicit tax rate $\tau_{t}$ which relates $I T_{t}^{t}$ to the life-time income of generation $t .^{26}$

$$
\tau_{t} \equiv \frac{I T_{t}^{t}}{w_{t}+R_{t+1}^{-1} w_{t+1}}=\frac{\theta_{t} w_{t}+R_{t+1}^{-1} \theta_{t+1} w_{t+1}-R_{t+2}^{-1} R_{t+1}^{-1} p_{t+2}}{w_{t}+R_{t+1}^{-1} w_{t+1}}
$$

(Applying this definition to form $\tau_{t-2}, \tau_{t-1}$ etc. is straightforward.) Denoting the growth factors of wage rates and cohort size by $w_{t+1} / w_{t}=G_{t+1}$ and $N_{t+1} / N_{t}=M_{t+1}$, respectively, and taking into account the periodic budget constraint for pay-as-you-go financing which ensures that $p_{t+2}=\theta_{t+2} W_{t+2} / N_{t}$ yields

$$
\begin{aligned}
& \tau_{t}=\frac{\theta_{t}+R_{t+1}^{-1} G_{t+1} \theta_{t+1}-R_{t+1}^{-1} R_{t+2}^{-1} G_{t+1} G_{t+2} M_{t+1}\left(1+M_{t+2}\right) \theta_{t+2}}{1+R_{t+1}^{-1} G_{t+1}} \\
& =\tau_{t}\left(R_{t+1}, R_{t+2}, G_{t+1}, G_{t+2}, M_{t+1}, M_{t+2}, \theta_{t}, \theta_{t+1}, \theta_{t+2}\right) \\
& (-) \quad(+)
\end{aligned}
$$

25 In conventional generational accounting, this time restriction is next to inevitable, at least if more than just one or two major branches of fiscal activities of the state shall be considered. Remember that, in order to assess the full life-time account for a 90-year old person in 2000, one needs to know a lot of details about the public tax-transfer system in the pre-World War I era. In many countries, information of this kind will no longer exist.

26 For an in-depth discussion, building on a fully developed annual structure of time periods, see Beckmann (2000). 
Certainly the most interesting results relate to how the implicit tax rate is affected by population ageing and by any variations in policy parameters $\{\theta, p\}$ or, taking into account the pay-as-you-go constraint, $\left\{\theta_{t}, \theta_{t+1}, \theta_{t+2}\right\}$. We defer this discussion to the subsequent section. For the moment, we will try to understand the nature and composition of $\tau_{t}$ more fully. In order to do so, let us consider a steady-state scenario where all the relevant growth rates are constant over time and policy remains unchanged. ${ }^{27}$ In this case, $\tau$ reduces to:

$$
\begin{gathered}
0<\tau=\theta\left[1-\frac{G^{2} M^{2}+G^{2} M}{R^{2}+R G}\right]<\theta \text { for } G M<R, \\
R_{t+1}=R_{t+2}=R, \quad G_{t+1}=\ldots=G, \quad M_{t+1}=\ldots=M, \quad \theta_{t}=\ldots=\theta
\end{gathered}
$$

In other words, even absent any problems of ageing, individuals will always forego part of their life-time income - or, more precisely, part of their life-time contributions when participating in an unfunded pension scheme simply because they are forced to make contributions to a (mandatory) pay-as-you-go system instead of placing true precautionary savings on the capital market. The reason is that, quite generally, the internal rate of return in unfunded pension schemes must be expected to fall short of the market rate of interest (on safe assets) which is used for discounting. In other words, it is just the usual "non-Aaron" condition $G M<R$ - that is required to hold for the economy to be dynamically efficient - which makes the return in unfunded pension schemes low and, in turn, constitutes an implicit tax falling on all those who pay contributions over their full life cycle before they are entitled to receive pensions (Sinn 2000; see the pioneering article by Aaron 1966).

Under reasonable assumptions, all the amounts of IT listed above will therefore be positive, thus indicating an effective burden which is placed on generations $t-2$ etc. At the same time, there are at least two generations - to be called generations " 0 " and " 1 ", with $t>3$ - who must have benefited from the unfunded pension scheme when it was inaugurated in periods 2 and 3 . The reason is that they were entitled to receive fullscale pension benefits without having contributed to the pay-as-you-go budget during their entire period of labour force participation. Formally,

$$
I T_{t}^{0}=-R_{3} \ldots R_{t} p_{2}\left(w_{0}, w_{1}\right) \text { and } I T_{t}^{1}=R_{3} \ldots R_{t} \theta_{2} w_{2}-R_{4} \ldots R_{t} p_{3}\left(w_{1}, \theta_{2} w_{2}\right){ }^{28}
$$

27 Clearly, in a steady state of the world there is no need to adjust contribution rates, at least as long as the level of pensions is not altered for some exogenous reasons.

28 Here, we assume that pensions related to periods of economic activity in which no contributions were made are generally based on the idea of maintaining earlier living standards. To some extent, they will therefore depend on wages received in these periods of life. 
with

$$
I D_{1}=R_{2}^{-1} p_{2}\left(w_{0}, w_{1}\right) N_{0}+R_{2}^{-1} R_{3}^{-1} p_{3}\left(w_{1}\right) N_{1},
$$

where $I D_{1}$ is the implicit debt created by establishing the unfunded pension system. It is easy to see that it is the same "gift" to some initial generations which makes the implicit tax for individuals in these generations negative and gives rise to the initial amount of debt that is generally implied in pay-as-you-go financing of current pensions. ${ }^{29}$

Note, in addition, that the period $t$ value of $I D_{1}, R_{2} \ldots R_{t} I D_{1}$, will be substantially larger than $I D_{t}$ if the parameters of the pension system have not changed by too much and if the interest rate implied in $R$ exceeds the growth rate of aggregate wages. In a stationary environment, this observation is true for $I D$ on absolute terms; in a scenario with steady-state growth, it holds true for the ratio of $I D$ over period $t$ wage income, i.e. for

$$
R_{2} \ldots R_{t} I D_{1} / W_{t}>I D_{t} / W_{t}=d_{t}
$$

Again, the interpretation is straightforward. By bearing the burden of an implicit tax $I T>0$, all generations who enter working-age in period 2 or later have contributed to keeping $I D$ within reasonable limits - for instance, keeping the current rate of $d$ a constant in a stationary state of the world or in a steady-state scenario. Taking into account the periodic pay-as-you-go constraint imposed on the pension system, this can best be seen from the fact that

$$
\sum_{j=0}^{t} I T_{t}^{j} N_{j}-\left(R_{t+1}^{-1} \theta_{t+1} w_{t+1}+R_{t+2}^{-1} R_{t+1}^{-1} p_{t+2}\left(\theta_{t+1} w_{t+1}\right)\right) N_{t}=-I D_{t} \quad \text { and } \quad \sum_{j=0}^{\infty} I T_{t}^{j} N_{j}=0 .^{30}
$$

If the inter-temporal aggregate of $I T$ for all past and present generations is corrected for those contributions and related benefits that are still open at date $t$, the sum of all implicit taxes gives just the amount of outstanding implicit debt. If aggregation across

29 By the time of enactment, $I D_{1}$ may not so much have appeared to be a gift. Rather, the introduction of pay-as-you-go pensions for generations 0 and 1 may have been motivated by the feeling that these generations were unable to provide for their old age for good reasons - for instance, because most of their assets were destroyed by an exogenous shock.

30 For a steady-state scenario, a rigorous demonstration is simple (see Sinn 2000). If, for simplicity, all current values are discounted to period 0 , then

$$
\sum_{j=0}^{\infty} I T_{0}^{j} N_{j}=\sum_{j=0}^{\infty} \tau_{j} \frac{G^{j} M^{j}}{R^{j}}(1+G / R) w_{0} N_{0} \quad \text { with } \tau_{0}=-\theta \frac{G^{2} M(1+M)}{R^{2}(1+G / R)}, \tau_{1}=\theta \frac{R G-G^{2} M(1+M)}{R^{2}(1+G / R)},
$$

while $\tau_{2}$ etc. are given by the above formula for $\tau$. Substituting these definitions for all $\tau$ and solving the geometrical series over $(G M / R)^{\prime}$ reveals that, on aggregate, all implicit taxes will just cancel out (provided that $G M<R$ ). 
generations goes to infinity, then we see that all implicit debt that was created when unfunded pensions were inaugurated will be paid off by generation 2 and all their successors. ${ }^{31}$ The fundamental lesson to be learnt from our considerations is therefore the following: whatever happens to exogenous economic variables and to policy parameters that are relevant for current values of $I D$ and $I T$, unfunded pension schemes are essentially a "zero-sum game" across all the generations involved.

The expectation that the tax implied in unfunded pensions will be positive for all present and future generations is largely supported when $\tau_{t}$ is measured empirically for a number of real-world pension systems (see Fenge and Werding 2003). Before considering in some more detail why this is likely outcome in the case of population ageing, there is final observation to be made which relates to the main purpose of our present paper. As we have seen, the notion of an implicit tax is intimately connected to the internal rate of return in unfunded pension schemes, which is basically given by $G M-1$. Sometimes, the latter has been regarded in itself as a useful measure for inter-generational imbalances involved in many pay-as-you-go pension schemes. Evidently, this view is not altogether wrong. If compared to $\tau_{t}$, however, the picture to be drawn based on internal rates of return alone is incomplete. For it is one thing to earn low returns when participating in a mandatory system of old-age provision; it is another to earn these low returns on 20 to 40 per cent of your life-time income.

This completes our introduction to the tax implied in unfunded pension schemes. It should have become apparent that the notion of an implicit tax is closely linked to the basic theory of unfunded pensions - in fact, it is located at the very heart of the pay-asyou-go mechanism. At the same time, it is easy to apply to an empirical context. Being a well-defined measure for the impact exerted by current public pension schemes on a micro-level, it can also be used for doing various kinds of behavioural analyses, proceeding to both efficiency and equity considerations. For instance, one can look at the inter-generational pattern of full life-time tax rates $\tau_{t}$ for a number of real-world examples, illustrating the effects of current pension reforms (Fenge and Werding 2003); alternatively, one can spell out the structure of annual, or "marginal", tax rates that are implicitly levied over a given individual's life cycle, highlighting the impact on periodic labour supply decisions from both a theoretical and an empirical perspective (Fenge, Übelmesser and Werding 2002). ${ }^{32}$

31 It should be clear that, within our 3-period setting, generation 1 is already involved in paying off part of the implicit debt of the pay-as-you-go system: the return on their period 2 contributions in terms of pensions $p_{3}\left(\theta_{2} w_{2}\right)$ must be expected to be lower than $r$, like for any of the following generations.

32 In the literature, there is an alternative use of the concept of "implicit taxes" involved in public pensions, referring to changes (notably, reductions) in life-time income through prolonged activity once the option of retiring early has become feasible (see, for instance, Gruber and Wise 1997 or Blöndal 


\section{The impact of ageing on implicit tax rates}

We have considered the impact of ageing on some of the above measures as we went along. Closer inspection into the nature of implicit taxes provides us with a new baseline for our further discussion. It is important to note that the problem with unfunded pensions is not so much that there is an implicit debt entailed in these systems, or that there is an implicit tax imposed on each generation who participates in one of these schemes once the system is in full operation.

As we have seen, even in a steady-state there will be some inter-generational redistribution going along with pay-as-you-go financing because one or more "initial" generations benefit from unfunded pensions, while subsequent generations have to pay the bill. Yet, if no instationarities occur the implicit tax rate will be constant for all these subsequent generations. Assessing this type of inter-generational redistribution which is built in any unfunded pension scheme as being fair or unfair is clearly a matter of its own. When demographic change enters the picture, however, the time series for $\tau_{2}$ etc. need no longer be balanced across generations. Rather, it is very likely to follow a systematic trend, constantly placing higher burdens on younger age-cohorts.

Note that in $\tau_{t}$ - as defined in section $2.4-M_{t+1}\left(1+M_{t+2}\right)$ is just the inverse of the old-age dependency ratio for period $t+2$. For variable $t$, the latter will become higher as population ages. ${ }^{33}$ Ceteris paribus, the tax falling on generation $t$ will therefore start to increase. When a new steady state is reached, $\tau$ will again be a constant for all subsequent generations, but it will be so on a higher level than before. This is the fundamental trend which can easily be observed in many industrialised countries.

In order to measure the precise time pattern of implicit tax rates, two further aspects are relevant, namely the type of policy reactions that are chosen and the timing of any pension reforms.

- If the intention is to keep up the level of current pension benefits, the most prominent option is to drive up $\theta_{t+2}$ when the shift in old-age dependency becomes effective. To some extent, this will off-set the increase in $\tau_{t}$. At the same time, it will necessarily feed through to an increase in $\tau_{t+1}$ etc.

- If, instead, $\theta$ is kept constant throughout the additional burden falling on generations $t+1$ etc. will be avoided. In this case, through lower benefits $p_{t+2}$, genera-

and Scarpetta 1999). It is easy to see, however, that this type of implicit taxation forms a special case of our broader concept, simply focussing on a particular sub-period of an individual's life cycle. Clearly, the net burden implied in paying social security contributions becomes all the more relevant, the easier individuals can evade it.

33 At the same time, there may be endogenous responses with respect to $G$ and $R$ that are not captured here. 
tion $t$ will just have to bear the burden of ageing that is incurred through their own choices with regard to fertility $\left(M_{t+1}\right)$ and the productivity of future human capital - which may be affected, for example, through expenditure on education and professional training (thus altering $\left.G_{t+1}\right){ }^{34}$

- Finally, $\theta_{t}$ and/or $\theta_{t+1}$ could be increased at an earlier stage of the ageing process in order to nourish some way of pre-funding for $p_{t+2}$. In our context, it is of secondary importance whether these funds are managed publicly or by private-sector agencies. A major qualification is just that these funds should be invested outside the public sector. In this case, a similar result will be obtained as in the previous one. $^{35}$ The only difference is that the effective level of pensions paid in $t+2$ will be higher, thus avoiding a situation where people may suffer a loss in terms of their living standard in old age, due to an insufficient level of public pension benefits and a lack in rational foresight. ${ }^{36}$

In reality, all of these "pure" strategies - adjustments in contribution rates and benefit levels, or pre-funding - can of course be combined to form rather complex reform packages, affecting the pattern of inter-generational distribution in many different ways. In any of these cases, the implicit tax rate that is placed on individuals belonging to different age-cohorts provides a comprehensive measure of the overall effects of ageing. Thus, simulations for the levels and trends of $\tau_{t}$ over a longer sequence of birth cohorts can be a useful device for illustrating the consequences of quite a number of different policy reactions that have effectively been taken, or are currently under consideration, in different countries (see again Fenge and Werding 2003 for an example).

To the best of our knowledge, the inter-generational distribution of fiscal burdens involved in demographic ageing - at least as far as it is channelled through the pension system - is nowhere actively managed by institutional controls that are built into current pension schemes. It merely just "happens" based on current policy rules that often were devised before anyone would have envisaged the problems of ageing and on a number of adaptations that have been made to avoid imbalances that are really extreme. In many existing public pension schemes that are operated on a defined-(level-of)-benefit basis increases in contribution rates which occur rather late in the process of ageing are still

34 In our stylised model, $\tau_{t}$ will also depend on choices taken by the next generation (regarding $M_{t+2}$ and $G_{t+2}$ ). In a more realistic setting, this might be considered with some more care when it comes to drawing policy conclusions. What is important, here, is the fundamental link between decisions that are currently taken and the "tax base" for funding future pensions.

35 By definition, the portion of $\theta_{t}$ and $\theta_{t+1}$ used for funding should not cause an additional burden for generation $t$-at least as long as the internal rate of return in the funded "pillar" is equal to $r$.

36 If there is a binding minimum income guaranteed outside the pension system, e.g. through social assistance, some degree of "myopic" behaviour may even be rational. In this case, there may be good reasons for making pre-funding mandatory on an individual level. 
most likely to be one of the most prominent ingredients in actual policy responses. In addition, the political economy of pension reform may strongly act in the same direction. Taking these observations together with the considerations made earlier in this paper, this dominant strategy of adapting current pension schemes to the problems caused by ageing can finally be interpreted as a continuous re-invention of public payas-you-go systems.

Building on Aaron (1966), a "constant contributions" regime can be regarded a natural benchmark case for running unfunded pension schemes: in this case, the internal rate of return of the system is simply given by the rate of aggregate payroll growth; the implicit pension debt will not respond too much to demographic ageing; and the calculation of implicit tax rates is straightforward. If, instead, contribution rates are increased at some point in time in order to maintain current pension benefits which otherwise could not be financed for, this is more than just an adjustment within the existing pension scheme. In a sense, another pay-as-you-go system is placed on top of the old one. New contributions (viz., $\Delta \theta$ ) are levied, and new introductory gains accrue to those who are currently retired. But, like in the old system, a fresh implicit debt is created at the same time which will have to be paid for through higher implicit tax rates that are imposed on all subsequent generations. Assessing the merits of this type of policy reaction in the presence of population ageing is clearly beyond the scope of our survey. But the logic applied can be easily detected using the implicit tax rate as a concept for measuring inter-generational imbalances involved in current pension systems, thus providing the tools that are needed for further analysis. 


\section{References}

Aaron, H. (1966), “The Social Insurance Paradox", Canadian Journal of Economics and Political Science 32, 371-374.

Auerbach, A., J. Gokhale and L. J. Kotlikoff (1991), "Generational Accounts: A meaningful alternative to deficit accounting”, in: D. Bradford (ed.), Tax policy and the economy, Vol. 5, Cambridge: MIT Press, 55-110.

Auerbach, A., L. J. Kotlikoff and W. Leibfritz (1999), Generational Accounting Around the World, Chicago: NBER.

Barr, N. (2000), "Reforming Pensions: Myths, Truths, and Policy Choices", IMF Working Paper No. 00/139.

Beckmann, K. (2000), "A note on the tax rate implicit in pay-as-you-go public pension contributions", Finanzarchiv N. F. 57, 63-76.

Blöndal, S. and S. Scarpetta (1999), "The Retirement Decision in OECD Countries", OECD Economics Department Working Paper No. 202.

Brooks, R. (2000), "What Will Happen to Financial Markets When the Baby Boomers Retire?", IMF Working Paper No. 00/18.

Chand, S. K. and A. Jaeger (1996), "Ageing Populations and Public Pension Schemes", IMF Occasional Paper No. 147.

Fehr, H. and L. J. Kotlikoff (1999), "Generational Accounting in General Equilibrium”, in: Auerbach et al. (eds., 1999), Generational Accounting Around the World, Chicago: NBER, 43-71.

Fenge, R. and M. Werding (2003), "Ageing and the tax implied in unfunded pensions: Simulations for selected OECD countries", CESifo Working Paper No. 841.

Fenge, R., S. Uebelmesser and M. Werding (2002), "Second-best properties of implicit social security taxes: Theory and evidence", CESifo Working Paper No. 743.

Franco, D. (1995), "Pension Liabilities - their Use and Misuse in the Assessment of Fiscal Policies", Working paper, Rome: Banca d'Italia.

Gruber, J. and D. Wise (1997), "Social Security Programs and Retirement Around the World", NBER Working Paper No. 6134.

Hagemann, R. P. and G. Nicoletti (1989), "Population Ageing: Economic Effects and Some Policy Implications for Financing Public Pensions", OECD Economic Studies No. 12.

Haveman, R. (1994), "Should Generational Accounts Replace Public Budgets and Deficits?", Journal of Economic Perspectives 8, 95-111. 
Holzmann, R., R. Palacios and A. Zviniene (2000), “On the Economics and Scope of Implicit Pension Debt: An International Perspective”, Paper prepared for the 2001 ASSA Meetings, New Orleans.

Homburg, S. and W. Richter (1990), "Eine effizienzorientierte Reform der GRV", in: B. Felderer (ed., 1990), Bevölkerung und Wirtschaft, Berlin: Duncker \& Humblot, 183-191.

Kotlikoff, L. J. and W. Leibfritz (1999), “An International Comparison of Generational Accounts", in: A. Auerbach et al. (eds., 1999), Generational Accounting Around the World, Chicago: NBER, 73-101.

Kotlikoff, L. J. and B. Raffelhüschen (1999), "Generational Accounting Around the Globe", in: American Economic Review, Papers and Proceedings 89, 161-166.

Leibfritz, W., D. Roseveare, D. Fore and E. Wurzel (1995), “Ageing Populations, Pension Systems and Government Budgets: How Do they Affect Savings?", OECD Economics Department Working papers No. 156.

Lüdeke, R. (1988), "Staatsverschuldung, intergenerative Redistribution und umlagefinanzierte Rentenversicherung”, in: J. Klaus and P. Klemmer (eds.), Wirtschaftliche Strukturprobleme und soziale Fragen, Berlin: Duncker \& Humblot, 167-181.

Organisation for Economic Co-operation and Development (1998), Maintaining Prosperity in an Ageing Society, Paris: OECD.

Organisation for Economic Co-operation and Development (2000), Reforms for an Ageing Society, Paris: OECD.

Organisation for Economic Co-operation and Development (2001), Economic Outlook No. 69 (June 2001), Paris: OECD.

Queisser, M. (1998), "The Second-Generation Pension Reforms in Latin America", OECD Ageing Working Papers No. AWP 5.4.

Roseveare, D., W. Leibfritz, D. Fore and E. Wurzel (1996), “Ageing Populations, Pension Systems and Government Budgets: Simulations for 20 OECD Countries", OECD Economics Department Working papers No. 168.

Sinn, H.-W. (1997), "The Value of Children and Immigrants in a Pay-as-you-go Pension System", NBER Working paper No. 6229.

Sinn, H.-W. (2000), "Why a Funded Pension is Useful and Why it is not Useful", International Tax and Public Finance 7, 389-410.

Sinn, H.-W. and M. Werding (2000), "Rentenniveausenkung und Teilkapitaldeckung. Ifo Empfehlungen zur Konsolidierung des Umlageverfahrens", Ifo Schnelldienst 53 (18/2000), 12-25. 
Thum, M. and J. v. Weizsäcker (2000), "Implizite Einkommensteuer als Messlatte für die aktuellen Rentenreformvorschläge", Perspektiven der Wirtschaftspolitik 1, 453468.

Van den Noord, P. and R. Herd (1993), "Pension Liabilities in the Seven Major Economies", OECD Economics Department Working paper No. 142.

Van den Noord, P. and R. Herd (1994), "Estimating pension liabilities: a methodological framework", OECD Economic Studies No. 23.

Werding, M. and H. Blau (2002), Auswirkungen des demographischen Wandels auf die staatlichen Alterssicherungssysteme, Ifo Beiträge zur Wirtschaftsforschung, Vol. 8, München: Ifo Institute.

World Bank (1994), Averting the Old-Age Crisis. Policies to Protect the Old and Promote Growth, Oxford, New York: Oxford University Press. 


\section{CESifo Working Paper Series}

(for full list see www.cesifo.de)

778 Antonio Merlo and François Ortalo-Magné, Bargaining over Residential Real Estate: Evidence from England, September 2002

$779 \mathrm{Yu}-\mathrm{Fu}$ Chen and Michael Funke, Exchange Rate Uncertainty and Labour Market Adjustment under Fixed and Flexible Exchange Rates, September 2002

780 Michael S. Michael, International Migration, Income Taxes and Transfers: A Welfare Analysis, September 2002

781 Clemens Fuest and Alfons Weichenrieder, Tax Competition and Profit Shifting: On the Relationship between Personal and Corporate Tax Rates, October 2002

782 Jan Bouckaert and Hans Degryse, Softening Competition by Enhancing Entry: An Example from the Banking Industry, October 2002

783 Johann K. Brunner and Susanne Pech, Adverse Selection in the Annuity Market with Sequential and Simultaneous Insurance Demand, October 2002

784 Gregory D. Hess and Eduard Pelz, The Economic Welfare Cost of Conflict: An Empirical Assessment, October 2002

785 Jan Erik Askildsen, Uwe Jirjahn, and Stephen C. Smith, Works Councils and Environmental Investment: Theory and Evidence from German Panel Data, October 2002

786 Geir H. Bjønnes, Dagfinn Rime, and Haakon O. Aa. Solheim, Volume and Volatility in the FX-Market: Does it matter who you are?, October 2002

787 John Evans and John Fingleton, Entry Regulation and the Influence of an Incumbent Special Interest Group, October 2002

788 Wolfgang Ochel, International Comparisons and Transfer of Labour Market Institutions, October 2002

789 B. Gabriela Mundaca, Moral Hazard Effects of Bailing out under Asymmetric Information, October 2002

790 Gene M. Grossman and Edwin L.-C. Lai, International Protection of Intellectual Property, October 2002

791 John Hassler, José V. Rodriguez Mora, Kjetil Storesletten, and Fabrizio Zilibotti, A Positive Theory of Geographic Mobility and Social Insurance, October 2002

792 Paul De Grauwe and Marianna Grimaldi, The Exchange Rate in a Model with Heterogeneous Agents and Transactions Costs, October 2002 
793 Guido Friebel and Mariassunta Giannetti, Fighting for Talent: Risk-shifting, Corporate Volatility, and Organizational Change, October 2002

794 Jan Erik Askildsen, Badi H. Baltagi, and Tor Helge Holmås, Will Increased Wages Reduce Shortage of Nurses? A Panel Data Analysis of Nurses' Labour Supply, October 2002

795 Marko Köthenbürger and Panu Poutvaara, Social Security Reform and Intergenerational Trade: Is there Scope for a Pareto-Improvement?, October 2002

796 Paul De Grauwe and Laura Rinaldi, A Model of the Card Payment System and the Interchange Fee, October 2002

797 Volker Böhm and Tomoo Kikuchi, Dynamics of Endogenous Business Cycles and Exchange Rate Volatility, October 2002

798 Mariam Camarero, Javier Ordóñez, and Cecilio Tamarit, The Euro-Dollar Exchange Rate: Is it Fundamental?, October 2002

799 Misa Tanaka, How Do Bank Capital and Capital Adequacy Regulation Affect the Monetary Transmission Mechanism?, October 2002

800 Jörg Baten and Andrea Wagner, Autarchy, Market Disintegration, and Health: The Mortality and Nutritional Crisis in Nazi Germany, 1933-1937, October 2002

801 Saku Aura, Uncommitted Couples: Some Efficiency and Policy Implications of Marital Bargaining, October 2002

802 Wolfram F. Richter, Delaying Integration of Immigrant Labor for the Purpose of Taxation, October 2002

803 Gil S. Epstein and Shmuel Nitzan, The Politics of Randomness, October 2002

804 John Hassler and José V. Rodriguez Mora, Should UI Benefits Really Fall over Time?, October 2002

805 Friedrich Breyer and Stefan Felder, The Dead-anyway Effect Revis(it)ed, October 2002

806 Assar Lindbeck and Solveig Wikström, E-exchange and the Boundary between Households and Organizations, November 2002

807 Dieter Bös, Contests Among Bureaucrats, November 2002

808 Steven Brakman, Harry Garretsen, and Marc Schramm, The Strategic Bombing of German Cities during World War II and its Impact on City Growth, November 2002

809 Florian Englmaier and Achim Wambach, Contracts and Inequity Aversion, November 2002 
810 Sarbajit Sengupta, Delegating Recruitment under Asymmetric Information, December 2002

811 Rajshri Jayaraman, On the Partial Public Provision of a Private Good, December 2002

812 Stéphanie Stolz, Banking Supervision in Integrated Financial Markets: Implications for the EU, December 2002

813 Christian Keuschnigg, Taxation of a Venture Capitalist with a Portfolio of Firms, December 2002

814 Inés Macho-Stadler and David Pérez-Castrillo, Settlement in Tax Evasion Prosecution, December 2002

815 Rainer Niemann and Dirk Simons, Costs, Benefits, and Tax-induced Distortions of Stock Option Plans, December 2002

816 Jan-Egbert Sturm and Barry Williams, Deregulation, Entry of Foreign Banks and Bank Efficiency in Australia, December 2002

817 V. Anton Muscatelli, Patrizio Tirelli, and Carmine Trecroci, Monetary and Fiscal Policy Interactions over the Cycle: Some Empirical Evidence, December 2002

818 Claude Hillinger, A General Theory of Price and Quantity Aggregation and Welfare Measurement, December 2002

819 Erkki Koskela and Ronnie Schöb, Optimal Capital Taxation in Economies with Unionised and Competitive Labour Markets, December 2002

820 Sheilagh Ogilvie, Guilds, Efficiency, and Social Capital: Evidence from German ProtoIndustry, December 2002

821 Hans Gersbach and Verena Liessem, Financing Democracy, December 2002

822 Costas Hadjiyiannis, Panos Hatzipanayotou, and Michael S. Michael, Optimal Tax Policies with Private-Public Clean-Up, Cross-Border Pollution and Capital Mobility, December 2002

823 François Ortalo-Magné and Sven Rady, Homeownership: Low Household Mobility, Volatile Housing Prices, High Income Dispersion, December 2002

824 Syed M. Ahsan and Panagiotis Tsigaris, Measuring the Social Discount Rate under Uncertainty: A Methodology and Application, December 2002

825 Kai A. Konrad, Altruism and Envy in Contests: An Evolutionarily Stable Symbiosis, December 2002

826 Robert S. Chirinko and Huntley Schaller, A Revealed Preference Approach to Understanding Corporate Governance Problems: Evidence from Canada, December 2002 
827 Geir B. Asheim, Green National Accounting for Welfare and Sustainability: A Taxonomy of Assumptions and Results, December 2002

828 Andrea Gebauer, Chang Woon Nam, and Rüdiger Parsche, Lessons of the 1999 Abolition of Intra-EU Duty Free Sales for Eastern European EU Candidates, December 2002

829 Giacomo Corneo, Work and Television, December 2002

830 Vivek H. Dehejia and Yiagadeesen Samy, Trade and Labour Standards - Theory, New Empirical Evidence, and Policy Implications, December 2002

831 Geir B. Asheim and Wolfgang Buchholz, A General Approach to Welfare Measurement through National Income Accounting, December 2002

832 Aaron Tornell and Frank Westermann, The Credit Channel in Middle Income Countries, January 2003

833 Gebhard Flaig, Time Series Properties of the German Monthly Production Index, January 2003

834 Campbell Leith and Jim Malley, Estimated Open Economy New Keynesian Phillips Curves for the G7, January 2003

835 Burkhard Heer and Bernd Süssmuth, Inflation and Wealth Distribution, January 2003

836 Erkki Koskela and Leopold von Thadden, Optimal Factor Taxation under Wage Bargaining - A Dynamic Perspective, January 2003

837 Carola Grün and Stephan Klasen, Growth, Income Distribution, and Well-Being: Comparisons across Space and Time, January 2003

838 Robert S. Chirinko and Ulf von Kalckreuth, On the German Monetary Transmission Mechanism: Interest Rate and Credit Channels for Investment Spending, January 2003

839 Sascha O. Becker, Andrea Ichino, and Giovanni Peri, How Large is the "Brain Drain" from Italy?", January 2003

840 Albert Berry and John Serieux, All About the Giants: Probing the Influences on Growth and Income Inequality at the End of the $20^{\text {th }}$ Century, January 2003

841 Robert Fenge and Martin Werding, Ageing and the Tax Implied in Public Pension Schemes: Simulations for Selected OECD Countries, January 2003

842 Robert Fenge and Martin Werding, Ageing and Fiscal Imbalances Across Generations: Concepts of Measurement, January 2003 